Rethinking Morphology 



\section{Rethinking Morphology}

Laurie Bauer 
Edinburgh University Press is one of the leading university presses in the UK. We publish academic books and journals in our selected subject areas across the humanities and social sciences, combining cutting-edge scholarship with high editorial and production values to produce academic works of lasting importance. For more information visit our website: edinburghuniversitypress.com

(C) Laurie Bauer, 2019

Edinburgh University Press Ltd

The Tun - Holyrood Road, 12(2f) Jackson's Entry, Edinburgh EH8 8PJ

Typeset in $10.5 / 12 \mathrm{pt} \mathrm{Janson} \mathrm{MT} \mathrm{by}$ Servis Filmsetting Ltd, Stockport, Cheshire and printed and bound in Great Britain.

A CIP record for this book is available from the British Library

ISBN 9781474436151 (hardback)

ISBN 9781474436168 (paperback)

ISBN 9781474436175 (webready PDF)

ISBN 9781474436182 (epub)

The right of Laurie Bauer to be identified as the author of this work has been asserted in accordance with the Copyright, Designs and Patents Act 1988, and the Copyright and Related Rights Regulations 2003 (SI No. 2498). 